\title{
The United Nations and
}

\section{Mozambique 1992-1995}

Nith an introduction by Boutros Boutros-Ghali, iecretary-General of the United Nations

This essential reference work offers a omprehensive account of one of the most nnovative, multifaceted and successful operations ver undertaken by the United Nations - the Jnited Nations Operation in Mozambique ONUMOZ). A combined effort of peaceeeping, humanitarian aid and electoral ssistance, ONUMOZ helped the Mozambican reople establish a solid foundation for a peaceful uture following a devastating civil conflict. $951.20 \quad 92-1-100559-0 \quad 321 \mathrm{pp} \quad \$ 29.95$

\section{Mozambique}

\section{The United Nations Blue Books Series}

his new series of pablications will prove an invaluable research and eference tool for academics, policy makers, fournalists and others iterested in gaining a deeper understanding of the work of the United Jations in dealing with the major issues of concern to humanity.

Ull the volumes will include an extensive introduction by ecretary-General Boutros Boutros-Ghali, a detailed chronology of events ind a collection of documents and related information. lach is available at $\$ 29.95$.

ther titles in the series include:

The United Nations and Apartheid, 1948-1994

The United Nations and Cambodia, 1991-1995

The United Nations and Nuclear Non-Proliferation

The United Nations and El Salvador, 1990-1995

United Nations Publications

Room DC2-0853, Dept. 341A, New York, N.Y. 10017

Tel. (800) 253-9646, (212) 963-8302, Fax. (212) 963-3489

Visa, MC and AMEX accepted.

Please add $5 \%$ of gross ( $\$ 3.50$ minimum) for shipping and handling. 


\section{RESEARCH IN \\ AFRICAN \\ LITERATURES}

\section{EDITOR:}

Abiola Irele

\section{SINGLE ISSUE:}

Individual, $\$ 10.00$

Institution, $\$ 20.00$

Postage, $\$ 1.75$ per issue

\section{SUBSCRIPTION}

(4 issues)

Individual, $\$ 35.00$

Institution, $\$ 60.00$

Foreign surface post, $\$ 12.50$

\section{SEND ORDERS TO:}

Indiana University Press

Journals Division

601 N. Morton Street

Bloomington, IN 47404

Phone: (812)855-9449

Fax: (812)855-8507

E-mail: Journals@Indiana.Edu
ISSUES OF SPECIAL INTEREST

African Cinema

Edited by Ken Harrow

Volume 26, number 3

New Voices in African Literature

Edited by Edna Aizenberg

Volume 26, number 1

Women as Oral Artists

Edited by Molara Ogundipe-Leslie and

Carole Boyce Davies

Volume 25, number 3

Caribbean Literature

Edited by Abiola Irele

Volume 25 , number 2

Oral Literature

Edited by Lilyan Kesteloot

Volume 24, number 2

North African Literature

Edited by Patricia Geesey

Volume 23, number 2

The Language Question Edited by Richard Bjomson

Volume 23, number 1

Research in African Literatures provides a stimulating forum for the discussion of the oral and written literatures of Africa. In addition, the journal serves the broader needs of the academic community by including reports on recent research, library archival resources, dissertations, and conferences in the field. Each issue includes a lively book review section, and there are frequent illustrations by African artists. 







\section{Selections in African Studies}

\section{from UCL PRESS}

ZAMBIAN CRISIS BEHAVIOUR Confronting Rhodesia's Unilateral Declaration of Independence, 1965-1966

Douglas G. Anglin

In this pioneering study Douglas Anglin describes and dissects the process of crisis decision making in Zambia through a detailed reconstruction of the most critical decisions of 1965-66, and assesses the effect of crisis-induced stress on the policy outcomes of President Kenneth Kaunda and other Zambian leaders.

Cloth $\quad 0.7735-1219-5$

$£ 28.00$

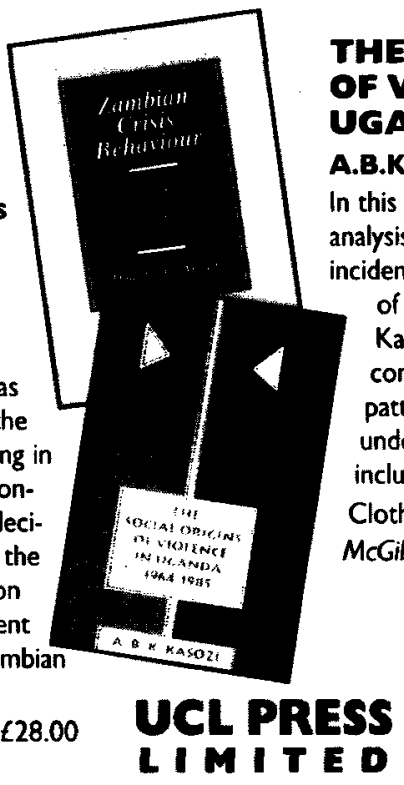

THE SOCIAL ORIGINS OF VIOLENCE IN UGANDA, 1964-1985

\section{A.B.K. Kasozi}

In this thorough and comprehensive analysis of the causes, levels, and incidence of more than two decades of violence in Uganda.A.B.K. Kasozi presents the first scholarly compilation and comparison of patterns and forms of violence under successive Ugandan regimes including the second Obote regime. Cloth $\quad 0-7735-1218-7 \quad £ 28.00$ McGill-Queen's University Press

University College London. Gower Street, London WCIE 6BT

Tel: $+44(0) 713807707$

Fax: $+44(0) 714138392$ 


\title{
THE JOURNAL OF
}

MODERN AFRIGAN

\section{STUDIES}

VOLUME 33, Nos I, 2, 3 \& 4

\author{
EDITED BY \\ DAVID KIMBLE
}




\section{PUBLISHED BY}

THE PRESS SYNDIGATE OF THE UNIVERSITY OF CAMBRIDGE

The Pitt Building, Trumpington Street, Cambridge CB2 IRP 40 West 2oth Street, New York, Ny 1001 1 -421 I, USA Io Stamford Road, Oakleigh, Melbourne 3166, Australia

c Cambridge University Press 1995

Printed in Great Britain by the University Press, Cambridge 


\section{THE JOURNAL OF MODERN AFRIGAN STUDIES}

The Joumal offers a quarterly survey of politics, economics, and related topics in contemporary Africa.

The main emphasis is upon the peoples and policies, the problems and progress of this dynamic and disparate continent; upon the many societies that are evolving rather than the essential characteristics of the old; upon the present, not on the more distant past. The best current work is presented from specialists in different academic disciplines, whose contributions can illuminate and cross-fertilise one another.

The Foumal seeks to promote a deeper understanding of what is happening in Africa today. It is intended for both the political scientist and the practical politician, the administrator and the advocate, the economist and the educator, the banker and the business man, the diplomat and the technocrat, the civil servant and the nationalist leader. All have something to contribute to these pages and, it is hoped, much to learn from them.

Editorial policy avoids commitment to any political viewpoint or ideology, whether imperialism, pan-Africanism, capitalism, socialism, or nationalism. Such concepts, however, have relevance to the modern African situation, and merit serious discussion, often from several different points of view, in order that controversial issues may be fairly examined.

Contributors of accepted articles will be asked to assign their copyright, on certain conditions, to Cambridge University Press, to help protect their material.

\section{Copying}

This journal is registered with the Copyright Clearance Center, 222 Rosewood Drive, Danvers, MA ol923. Organisations in the USA who are also registered with C.C.C. may therefore copy material (beyond the limits permitted by sections 107 and 108 of US copyright law) subject to payment to C.C.C. of the per copy fee of $\$ 7.50$. Code $0022-278 x / 95 / \$ 7.50+.10$. This consent does not extend to multiple copying for promotional or commercial purposes. ISI Tear Sheet Service, 350 I Market Street, Philadelphia, Pennsylvania 19104, USA, is authorised to supply single copies of separate articles for private use only. Organisations authorised by the Copyright Licensing Agency may also copy material subject to the usual conditions. For all other use, permission should be sought from Cambridge or the American Branch of Cambridge University Press.

C Cambridge University Press 1995

\section{CAMBRIDGE UNIVERSITY PRESS}

The Pitt Building, Trumpington Street, Cambridge CB2 IRP

40 West 2oth Street, New York, NY IOon I-421 I, USA

Io Stamford Road, Oakleigh, Melbourne 3166, Australia 

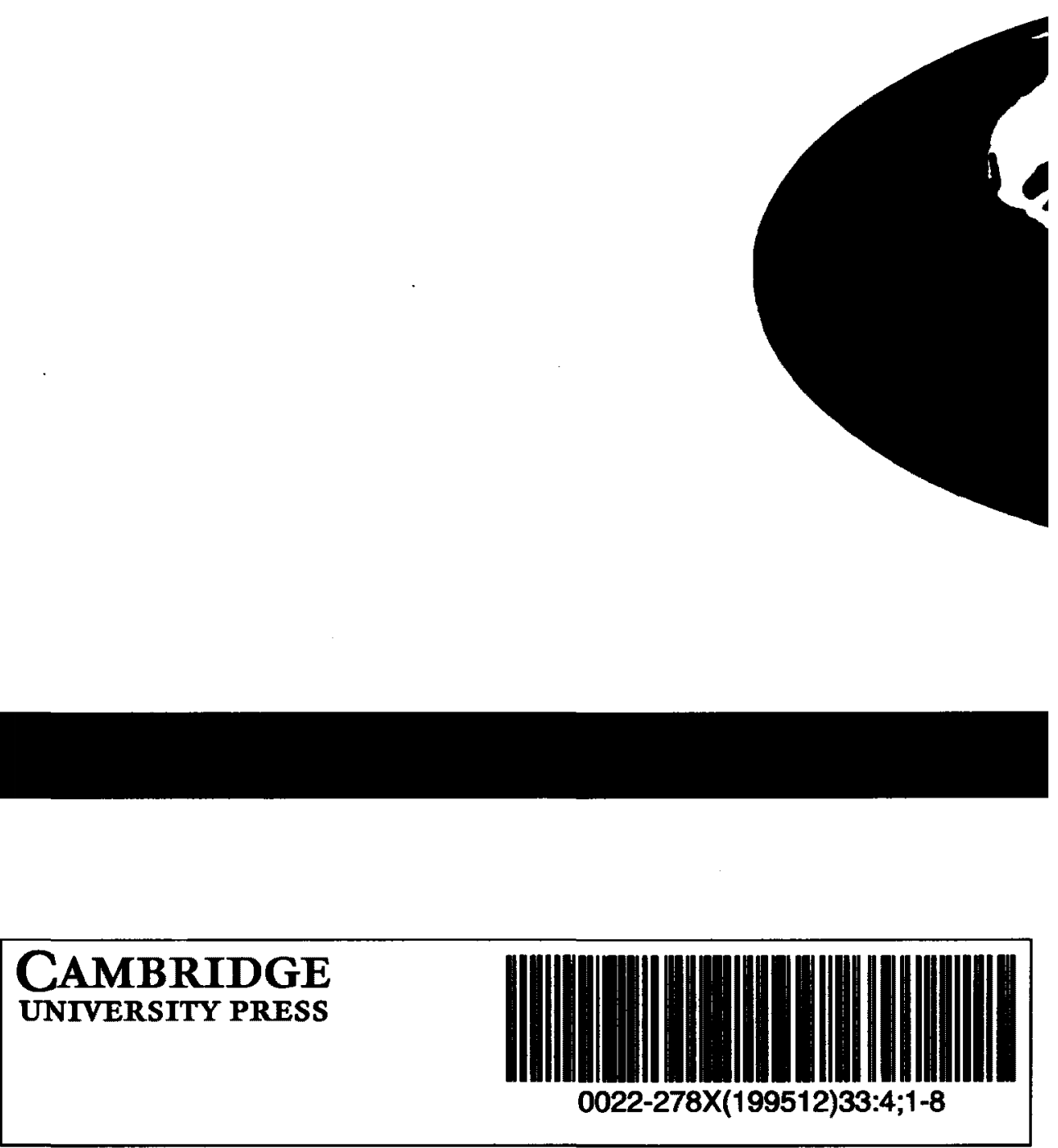